\title{
Performance Enhancement and Emissions Analysis of Diesel Engine with Biodiesel, N-Propanol and 1-Butanol Blend
}

\author{
M. Vijayakumar ${ }^{1 \dagger}$ and P. C. Mukesh kumar ${ }^{2}$ \\ ${ }^{1}$ Department of Mechanical Engineering, M.Kumarasamy College of Engineering, Karur, Tamilnadu, \\ 639113, India. \\ ${ }^{2}$ Department of Mechanical Engineering, University College of Engineering,Dindugl, Tamilnadu, 64223, \\ India.
}

†Corresponding Author Email: vijithermal@gmail.com

(Received February16, 2017; accepted July 30, 2017)

\begin{abstract}
An experimental investigation is conducted to evaluate the effects of using blends of 1-Butanol, n-Propanol and biodiesel with base diesel fuel, with 5\% and 10\% (by vol.) each alcohol fuel (1-Butanol and n-Propanol), on the diesel engine performance and exhaust gas emissions. The experimental investigation of the above fuel blends, with the engine working at different loads. Engine performance and exhaust gas emissions such as nitrogen oxides, carbon monoxide, carbon dioxide, unburned hydrocarbons and smokiness are measured. The measured results of alcohol fuel blends with different concentration compared with base diesel fuel results. It is revealed that this fuel, which can be produced from alcohol fuel blend with biodiesel and base diesel blends, is very promising biodiesel performance enhancement of diesel engine operations. The present work proved that the $5 \%$ of alcohol fuel blend with $25 \%$ of biodiesel and diesel produced maximum efficiency and minimize the exhaust emission level compare with $10 \%$ of alcohol blend and base diesel.
\end{abstract}

Keywords: Diesel engine; 1-Butanol; N-Propanol; Emission; Performance.

\section{NOMENCLATURE}

BTE

specific fuel consumption

BP brake power

CO carbon monoxide

\author{
HC hydro carbon \\ $\mathrm{NOx}$ nitrous oxide \\ $\mathrm{CO}_{2} \quad$ carbon di oxide
}

\section{INTRODUCTION}

Diesel engine plays a very important role for road transport. The diesel engine powered by petroleum diesel fuel. The demand of diesel fuel engorges the research on alternative fuel. The researchers found, vegetable oil and animal fat is a major source for alternative fuel extraction. Demirbas (2008a) compared these two source transesterification and its components effects. Lapuerta et al.(2008) reviewed that the effect of alternative fuel on diesel engine performance and emissions. They mentioned important factors which mainly affect the engine performance and emissions, such as lower heating values, viscosity, chemical bonding and density. Palash et al.(2013), Hoekman et al. (2012), Fernando
(2006) mentioned that the major emissions from alternative fuels. NOx and soot consider as a major pollutant in CI engine exhaust, unfortunately alternative fuels also increase these types of pollutants due to high combustion temperature and fuel NOx. Demirbas (2008b) studied on Cotton seed biodiesel preparation and its properties. The cotton seed oil has a higher viscosity, lower cetain number and heating values. Nabi et al. (2009) investigated performance and exhaust emission on diesel engine powered by cotton seed biodiesel. The biodiesel concentration results shown less CO, PM and smoke emission than neat diesel fuel. NOx emission with biodiesel concentration shows higher values when compared with neat diesel fuel. The higher oxygen molecules present in the biodiesel were the main 
reason for results. The brake thermal efficiency of biodiesel concentration was lower than the neat diesel fuel due to lower heating values of the mixtures, volatility, higher viscosity and higher density. Oguzhan Dogan (2011) studied the performance development and emissions reduction of a single cylinder diesel engine at a constant engine speed and different loads by using n-butane blended diesel fuel. Butane can blend with diesel fuel easily. The brake thermal efficiency and brake specific fuel consumption were increased little with increasing butane content in the fuel. The exhaust emissions were $\mathrm{NOx}, \mathrm{CO}$, smoke was reduced with increasing butane content in the fuel, but $\mathrm{HC}$ pollutant was reduced significantly with increasing butane content in the fuel. Xiaolei (2012) reported ignition delay period for iso butanol-diesel blend and n-butanoldiesel blend. A result shows that $\mathrm{n}$ butanol- diesel blend took some longer ignition delay compare with Iso butanol - diesel blend. Iso butane produced higher cylinder peak pressure and higher pre mixed combustion heat release rate compare with nbutanol. Lower Soot emissions produced by nbutanol compare with isobutene. Ibrahim (206) found that the effect of diesel, biodiesel and dieselbiodiesel-butanol mixtures on diesel engine performance and emissions. Zhang (2016) investigated that the effect of butanol and pentanol on diesel engine performance and emissions. It observed significant change in particulate mass and elemental carbon emission with no significant change in the performance. Balamurugan et al. (2014) investigated performance and emission analysis of the diesel engine with the blend of $n-$ propanol at different proportions. The blending of npropanol with diesel shows augments the brake thermal efficiency at the maximum load condition and reduces the brake specific fuel consumption at medium and maximum load . However, the npropanol blend reduces engine operating temperature which is cause to generate $\mathrm{NOx}$ emissions, so notable NOx reduction was achieved. The maximum $\mathrm{HC}$ produced with n-propanol blended fuel at maximum load and lower CO noted at medium and higher load ranges. This present experimental study discussed about the impact of diesel engine performance and emission when the engine powered diesel and mixture of different proportionate diesel-butanol-propanol with $25 \%$ of biodiesel blend. The diesel engine powered by two different combinations of fuel (D55 and D65) and five different loads $(20 \%, 40 \%, 60 \%, 80 \%$ and $100 \%)$.

\section{EXPERIMENTAL SETUP}

A sequence of test was carried out to investigate the power of 1-butanol, n-propanol, biodiesel and diesel fuel blends in a single cylinder, four stroke, unmodified, air cooled, naturally aspirated engine and five engine loads by using 1-butanol, npropanol, biodiesel and diesel fuel blends. The experimental set up (Fig.1) consisted of a diesel test engine, SAJ test plant made AG10 eddy current DC dynamometer with APEX made AX-155 model constant speed $230 \mathrm{~V}$ loading unit, fuel flow meter, and exhaust gas analysis systems. The engine specification details used in the experiments are given in the Table 1. Dynamometer used to take engine torque and speed. The amount of fuel consumption was calculated by using fuel meter, which included a mass burette and a chronometer. Ktype thermocouple connected to the digital display unit was in the measurement of exhaust gas temperature. Emissions ( $\mathrm{HC}$ and $\mathrm{NO}$ in ppm, $\mathrm{CO}$, $\mathrm{CO} 2$ and $\mathrm{O} 2$ in percentage volume) were measured by an AVL $473 \mathrm{C}$ exhaust gas analyzer and smoke opacity (in percent) was measured by the AVL smoke meter. The specification of the exhaust gas analyzer and smoke meter are given in Table 2 . Exhaust gas measuring device AVL 473C determines the emissions of $\mathrm{CO}, \mathrm{HC}$ with means of infrared measurement (Non-dispersive infra-red) and NO with a means of electrochemical sensors. The test engine was not modified in any way for use with fuel blends. Data were collected for the engine torque, engine power, brake specific fuel consumption (BSFC), brake thermal efficiency (BTE), exhaust gas temperature, smoke opacity, $\mathrm{CO}$, $\mathrm{HC}$ and NOx emissions. The nomenclature and accuracy of the measurements and the uncertainty of the computed results of the parameters are given in Table 2 .

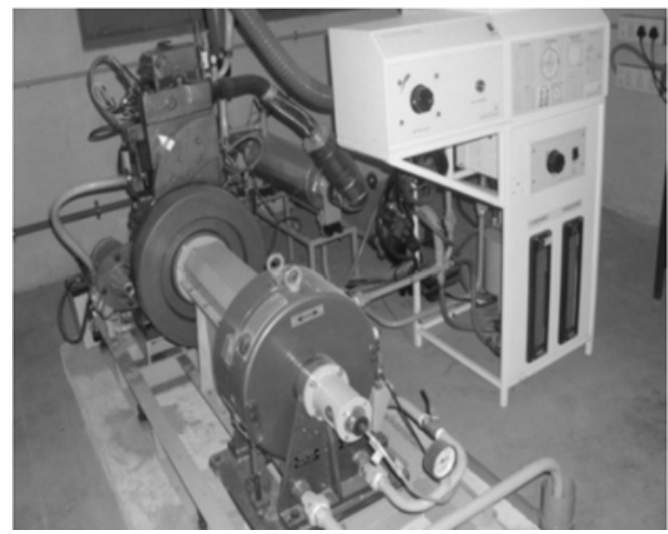

Fig. 1. Experimental Setup.

Table 1 Test engine specifications

\begin{tabular}{|c|c|}
\hline Particulars & Specifications \\
\hline Manufacturer & Kirloskar \\
\hline Type & $\begin{array}{c}\text { Four stroke, single cylinder, } \\
\text { Direct injection, VCR } \\
\text { engine }\end{array}$ \\
\hline Bore & $87 \mathrm{~mm}$ \\
\hline Stroke & $110 \mathrm{~mm}$ \\
\hline Compression ratio & $17: 1$ \\
\hline Engine speed & $1750-1690$ RPM \\
\hline Fuel injection pressure & 210 bar \\
\hline Injection timing & $23^{\circ}$ BTDC \\
\hline Cooling system & Water cooled engine \\
\hline
\end{tabular}


Table 2 Uncertainty and measuring range of gas analyzer and smoke meter

\begin{tabular}{|c|c|c|c|}
\hline S.No & Pollutant & Range & Accuracy \\
\hline 1 & $\mathrm{CO} \%$ Vol & $0-10$ & \pm 0.03 \\
\hline 2 & $\mathrm{CO}_{2} \%$ Vol & $0-20$ & \pm 0.5 \\
\hline 3 & $\mathrm{HC} \mathrm{ppm} \mathrm{Vol}$ & $0-20000$ & \pm 10 \\
\hline 4 & $\mathrm{O}_{2} \% \mathrm{Vol}$ & $0-22$ & \pm 5 \\
\hline 5 & $\mathrm{NO}$ ppm Vol & $0-5000$ & \pm 10 \\
\hline 6 & SMOKE $\%$ & $0-100$ & \pm 1 \\
\hline
\end{tabular}

In this study, experiments were performed at the engine speed of $1750-1690$ RPM and varying engine loads of $20 \%, 40 \%, 60 \%, 80 \%$ and $100 \%$. Tests were carried out initially using diesel fuel to generate the reference line data, and it was called on figures as "D100". Then, biodiesel, n-Propanol and 1-butanol blend with diesel (D55 and D65) were prepared and test under the same conditions for comparison.

\begin{tabular}{|c|c|c|c|c|}
\hline \multicolumn{5}{|c|}{ Table 3 Fuel properties } \\
\hline Properties & Diesel & $\begin{array}{c}\text { Cotton } \\
\text { Seed }\end{array}$ & $\begin{array}{c}1- \\
\text { Butanol }\end{array}$ & n-Propanol \\
\hline $\begin{array}{l}\text { Viscosity at } \\
40^{\circ} \mathrm{C} \mathrm{mm}^{2} / \mathrm{s}\end{array}$ & 3.9 & 6 & 3.64 & 2.8 \\
\hline $\begin{array}{c}\text { Density } \\
\mathrm{kg} / \mathrm{m}^{3} \text { at } 15^{\circ} \mathrm{C}\end{array}$ & 835 & 850 & 811 & 803 \\
\hline $\begin{array}{l}\text { Cetane } \\
\text { Number }\end{array}$ & 50 & 52 & Max 25 & 15 \\
\hline Flash Point & $>52^{\circ} \mathrm{C}$ & $162^{\circ} \mathrm{C}$ & $35^{\circ} \mathrm{C}$ & $22^{\circ} \mathrm{C}$ \\
\hline $\begin{array}{c}\text { Auto Ignition } \\
\text { Temperature } \\
{ }^{\circ} \mathrm{C}\end{array}$ & $>250^{\circ} \mathrm{C}$ & - & 385 & 371 \\
\hline $\begin{array}{c}\text { Heating Value } \\
\mathrm{MJ} / \mathrm{kg}\end{array}$ & 43.92 & 41.68 & 33.1 & 30.68 \\
\hline
\end{tabular}

The purity of the reference diesel fuel is $99.5 \%$, 1butanol is $99 \%$, and n-propanol is $99 \%$ were purchased from a commercial supplier. The 1-butanol and npropanol contain with $0.2 \%$ of water content. The properties of the fuels used in this study are presented in Table 3. It was observed that biodiesel, 1-butanol and n-propanol blended easily with reference diesel fuel and no homogeneity problem were seen with the fuel blends.

\section{RESULTS}

The $25 \%$ of biodiesel and different ratios of alcohol fuels mixed with diesel. The different alcohol fuels (Butanol and porpanol) mixed with different ratios (each $5 \%$ and $10 \%$ ). The $25 \%$ of biodiesel mixed with two different alcohol fuels like $5 \%$ of Butanol and $5 \%$ of propanol and $10 \%$ of butanol and $10 \%$ propanol. The above blend ratio made some difference with diesel concentration. The detailed blend ratio mentioned in Table 4.
Table 4 The volume ratio of blending.

\begin{tabular}{|c|c|c|c|}
\hline Chemical Content & Diesel & D55 & D65 \\
\hline Diesel \% Vol & 100 & 55 & 65 \\
\hline Bio diesel \% Vol & - & 25 & 25 \\
\hline n-Propanol \% Vol & - & 10 & 5 \\
\hline 1-Butanol \% Vol & - & 10 & 5 \\
\hline
\end{tabular}

\subsection{Engine Performance}

The discussion of the results and their justification of biodiesel/alcohol fuel blend (1-butanol and npropanol) with diesel fuel on diesel engine performance and emissions. The test engine maximum load calculated and it was applied like $20 \%, 40 \%, 60 \%, 80 \%$ and full load conditions with different fuel combinations like base diesel, D55, D65.

Figure2 shows that the brake thermal efficiency of different ratios of alcohol fuels mixed with $25 \%$ of biodiesel and diesel fuel. The significant impact observed from 1-Butanol and n-Propanol combinations. Alcohol fuel/biodiesel/diesel blend produced maximum efficiency compare with base diesel fuel. Especially D65 produced maximum brake thermal efficiency at entire load conditions, that is $5 \%$ of each 1-Butanol and n-Propanol blend produced maximum efficiency compared with $10 \%$ of each 1-Butanol and n-Propanol blend. The effect of alcohol fuels combination (1-Butanol and nPropanol) and biodiesel blend with diesel fuel reduces the fuel viscosity, it's improved the spray characteristics and resulted high brake thermal efficiency.Higher chain alcohol with a four carbon structure and it is known that larger chain alcohol fuel has higher burning velocities. Higher laminar flame speed obtained from alcohol/biodiesel/diesel combustion owing to improved engine brake thermal efficiency.Fig. 3 shows that the brake specific fuel consumption of base diesel, D55 and D65 fuels. The fuel D65 consumed minimum level of producing same output power which is producing other blends. Two alcohol fuel concentration with biodiesel and diesel mixture consumed minimum fuel compare with base diesel results. The $5 \%$ of alcohol blends produced more power with a minimum amount of fuel supply compared with $10 \%$ of alcohol fuel supply.In this observation clearly mentioned $5 \%$ of alcohol fuel produced good results with biodiesel combustion and in this

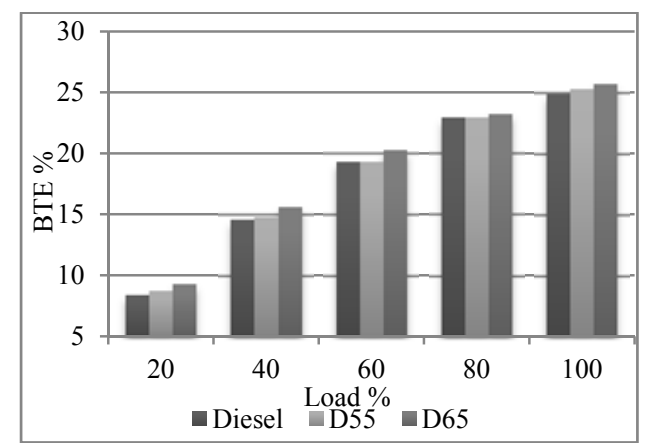

Fig. 2. Brake thermal efficiency with different load and different blend. 


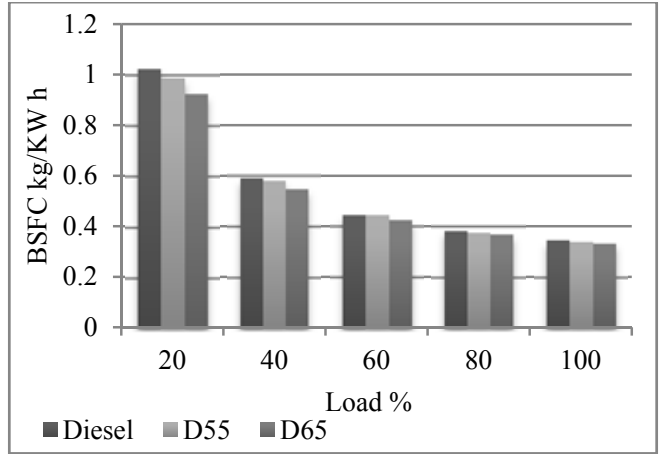

Fig. 3. Specific fuel consumption with different load and different blend.

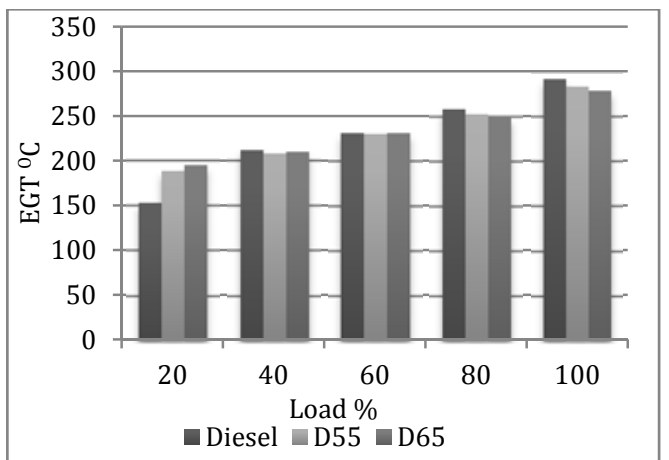

Fig. 4. Exhaust gas temperature with different load and different blend.

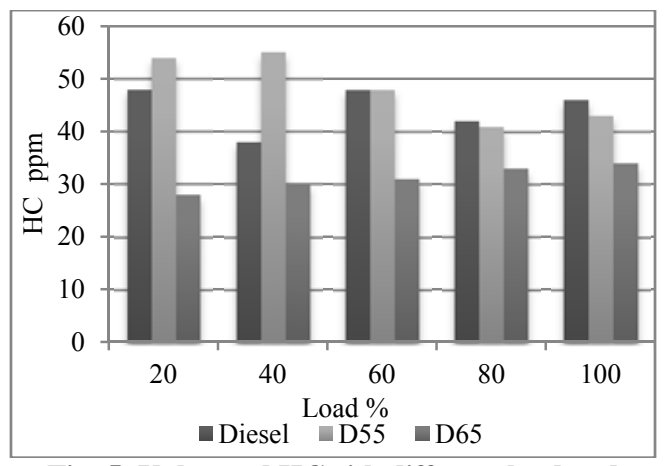

Fig. 5. Unburned HCwith different load and different blend.

effect due to fast vaporization and lesser viscosity of blending fuel causes of reduced specific fuel consumption. Improve the injection spray quality it chooses to make effective combustion. The fuel viscosity further reduced when increasing the alcohol fuels ( $10 \%$ of butanol and propanol). It causes to affect the injection pressure and timing. It was observed, $10 \%$ of alcohol fuel consumedmost amount of fuel compared with $5 \%$ of alcohol fuel blend with $25 \%$ of biodiesel.

\subsection{Exhaust Gas Emissions}

Figure 5 shows that the effect of 1-Butanol, n-Propanol and biodiesel with base diesel fuel on hydrocarbon (HC) production as a function of engine load. It was observed that the $41 \%$ of $\mathrm{HC}$ reduction in D65 fuel at $20 \%$ of load, but D55 increases $44 \%$ of $\mathrm{HC}$ at $40 \%$ of load compared with base diesel fuel. D65 reduced HC for entire engine load due to biodiesel concentration. Sun (2010) mentioned that the impact of biodiesel emission. Most of the researcher biodiesel produced minimum $\mathrm{HC}, \mathrm{CO}$ and $\mathrm{PM}$ and maximum $\mathrm{NOx}$, due to has a high rate of evaporation of alcohol fuels and biodiesel ignition delay.

Much amount of alcohol fuel (10\%) its touch with the cylinder wall fuel condensed and its make hydrocarbon pollutant. It is clearly indicated in exhaust gas temperature (EGT). D55 produced lesser amount of EGT, which is shown in Fig. 4. The $5 \%$ of alcohol blend with diesel and biodiesel blend makes effective combustion.

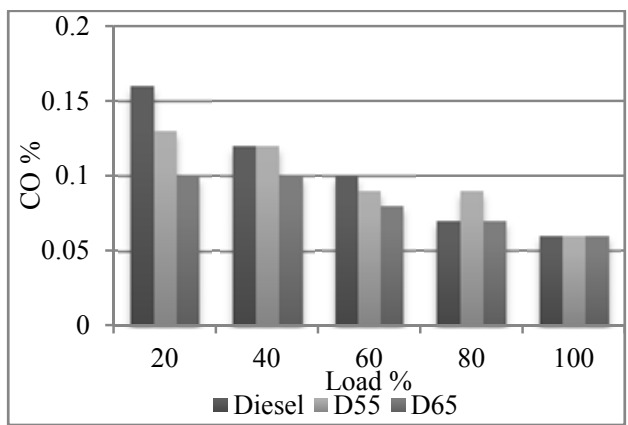

Fig. 6. Carbo monoxide with different load and different blend.

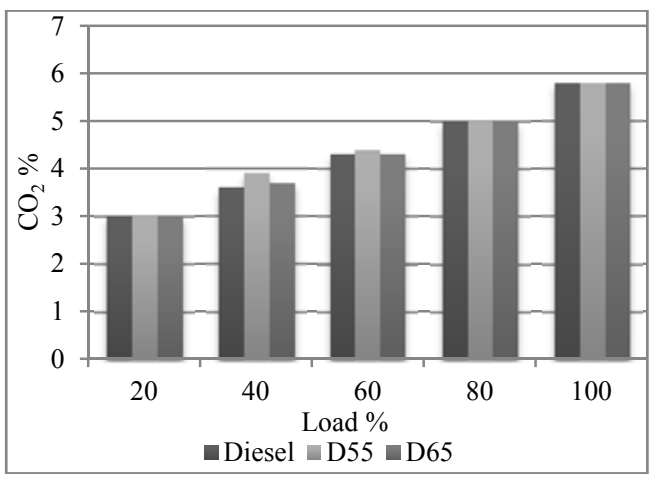

Fig. 7. Carbon dioxide with different loadand different blend.

Figure 6 shows the comparisons of carbon monoxide (CO) of different alcohol/biodiesel and diesel fuel blends. The minimum $\mathrm{CO}$ emitted by D65 fuel during all engine loads. The $5 \%$ of each alcohol fuel reduces the $\mathrm{CO}$ emissions effectively. However, D55 produced higher CO compare with D65. Fig. 7 shows the effect of different alcohol/biodiesel and diesel fuel blends on $\mathrm{CO}_{2}$. The minimum $\mathrm{CO}_{2}$ observed from D65 fuel at entire engine loads. The percentage of $\mathrm{CO}_{2}$ increases with increasing engine loads. The $5 \%$ of each alcohol fuel reduces the $\mathrm{CO}_{2}$ emissions effectively. However, D55 produced higher CO compare with D65. Fig. 8 shows that the effect of different concentration of different alcohol fuel/biodiesel and diesel fuel blends on NOx formation. The NOx formation increases with increasing engine loads due to increasing combustion temperature. Results show that the maximum NOx formation observed with D65 fuel 
blends. The 1-Butanol and n-Propanol blend increases with decreasing engine exhaust NOx level. The lower heating value of fuel blend with diesel and biodiesel, it causes to reduce the combustion temperature which is very important mechanisms of (Zolodich method) NOx formation. The lower combustion temperature observed in exhaust gas temperature.

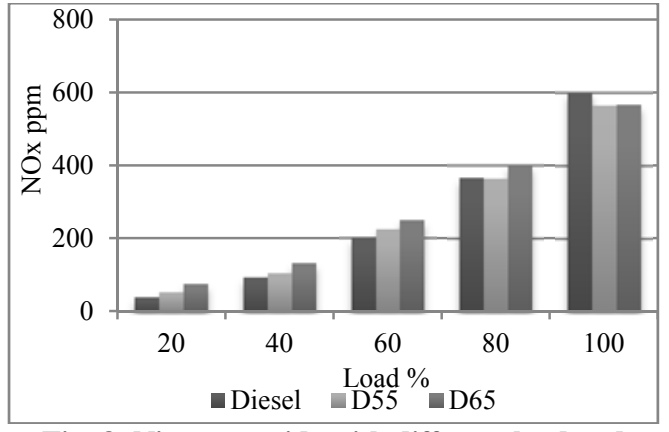

Fig. 8. Nitrogen oxide with different load and different blend.

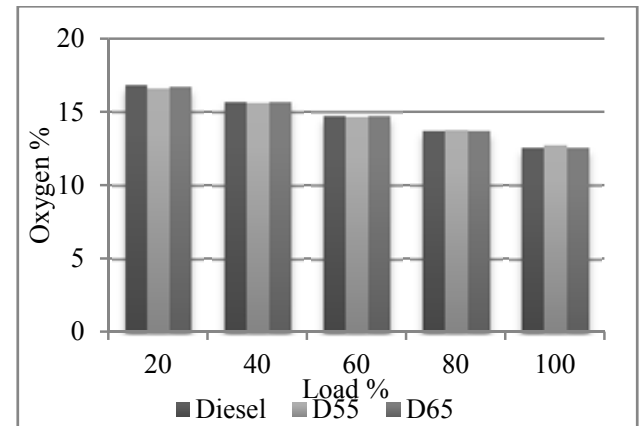

Fig. 9. Excess oxygen with different load and different blend.

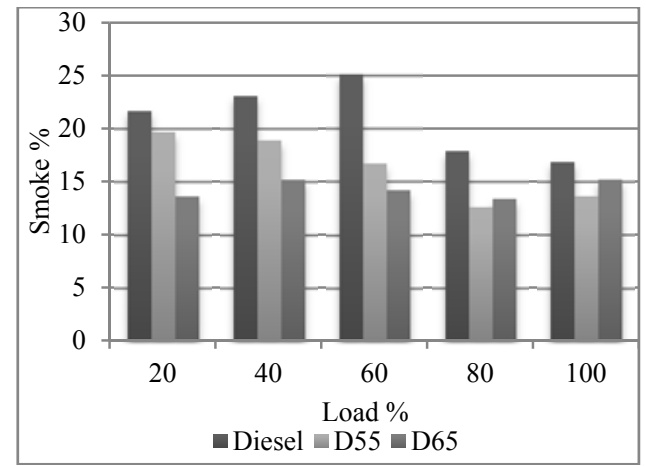

Fig. 10. Smoke with different load and different blend.

Figure 9 shows that the excess oxygen level in the exhaust gas of different alcohol fuel/biodiesel and diesel fuel blends with various engine loads. The excess oxygen percentage decreases with increasing engine loads. The Figs. 6, 7 and 9 clearly show that the $\mathrm{CO}, \mathrm{CO} 2$ and excess oxygen percentage in exhaust emissions. Carbon monoxide reacts with oxygen, it causes to produce carbon dioxide. $\mathrm{CO}$ and $\mathrm{O}_{2}$ level decreases with increasing $\mathrm{CO}_{2}$ level.
The smoke particulate matter is shown in Fig. 10. The maximum smoke particulate observed D55 at $20 \%$, $40 \%$ and $60 \%$ loads. The D65 fuel blends produced maximum smoke particulate emissions by $80 \%$ and $100 \%$ loads. All the alcohol blends produced lower smoke particulate compare with base diesel fuel. The biodiesel and alcohol fuel make negative effect on smoke particles [Nabi \& Dogan] Oxygen content of fuel and ignition delay is a causes to produced minimum smoke in alcohol fuel.

\section{CONCLUSION}

In this present work, the performance and emission of diesel engine were investigated for different load by using different percentage of 1- diesel, Butanol and n-Propanol mixed with $25 \%$ of biodiesel. The results showed that 1-Butanol and n-Propanol content of fuel blends has an important effect on diesel engine performance and emissions. The following conclusions can be drawn from the present work,

- 1-Butanol and n-Propanol can be blended with base diesel and biodiesel fuel easily without phase separation.

- D65 produced maximum BTE compared with all other fuel blend.

- The minimum SFC observed D65 blend compare with entire fuel blends. Significant performance notified with D65 fuel blend.

- D55 produced maximum HC emission

- Base diesel fuel produced maximum $\mathrm{CO}$ and smoke

- D65 produced maximum efficiency and minimum emission compare with all other blend.

From this work proved that $5 \%$ of alcohol fuel blends suitable with $25 \%$ of biodiesel blend with diesel fuel and $10 \%$ of alcohol fuel blend not efficient with $25 \%$ biodiesel blend with diesel fuel. D65 fuel considers for suitable blend for operating diesel fuel with biodiesel.

\section{REFERENCES}

Balamurugan, T. and R. Nalini (2014). Effect of Blending Alcohol with Diesel on Performance, Combustion and Emission Characteristics of Four Stroke Diesel Engine- An Experimental Study, International Journal of Chemical Tech Research 6(1), 750-762.

Demirbas, (2008a). Comparison of transesterification methods for production of biodiesel from vegetable oils and fats, Energy Conversion and Management 49(1), 125-130.

Demirbas, A. (2008b). Studies on cottonseed oil biodiesel prepared in non-catalytic SCF conditions. Bioresource Technology 99 (5), 1125-1130.

Doğan, O. (2011). The influence of n-butanol/diesel 
M. Vijayakumar and P. C. Mukesh kumar / JAFM, Vol. 10, Special Issue, pp. 79-84, 2017.

fuel blends utilization on a small diesel engine performance and emissions. Fuel 90(7), 24672472.

Fernando, S., C. hall and S. Jha (2006). NOx reduction from biodiesel fuels. Energy and fuels 20 376-82.

Gu, X., G. Li, X. Jiang, Z. Huang and C. Lee (2012). Experimental study on the performance of and emissions from a low-speed light-duty diesel engine fueled with n-butanol-diesel and isobutanol-diesel blends, Proceedings of the Institution of Mechanical Engineers, Part D: Journal of Automobile Engineering.

Hoekman, S. K. and C. Robbins (2012). Review of the effects of biodiesel on NOx emissions,Fuel Processing Technology 96 237-249.

Ibrahim, A. (2016). Performance and combustion characteristics of a diesel engine fuelled by butanol-biodiesel-diesel blends, Applied Thermal Engineering 103, 651-659

Lapuerta, M., O. Armas and J. Rodríguez Fernández, (2008). Effect of biodiesel fuels on diesel engine emissions, Progress in Energy and Combustion Science 34(2), 198-223.

Nabi, M. N., M. M. Rahman and M. S. Akhter (2009). Biodiesel from cotton seed oil and its effect on engine performance and exhaust emissions. Applied Thermal Engineering, 29(11-12), 22652270.

Palash, S. M., M. A. Kalam, H. H. Masjuki, B. M. Masum, I. Fattah and M. Mo (2013). Impacts of biodiesel combustion on NO $\mathrm{x}$ emissions and their reduction approaches 23(x), 473-490.

Sun, J., J. A. Caton and T. J. Jacobs (2010). Oxides of nitrogen emissions from biodiesel- fuelled diesel engine, progress in energy and combustion science 36, 677-95.

Zhang, Z. H., S. M. Chua and R. Balasubramanian (2016). Comparative evaluation of the effect of butanol-diesel and pentanol-diesel blends on carbonaceous particulate composition and particle number emissions from a diesel engine.Fuel 176, 40-47. 